\title{
Research on the Pricing Strategies of B2C of Electronic Commerce Based on the Game Theory
}

\author{
Tao Ye \\ Wuhan University of Technology \\ Wuhan Sports University \\ Wuhan, China
}

\author{
Jinjin Li \\ Wuhan University of Technology \\ Wuhan, China
}

\begin{abstract}
The vigorous development of the Internet has been prompting the transactions of online shopping to grow continuously, but behind the increasing amount of transactions are the financial loss reports of $\mathrm{B} 2 \mathrm{C}$ websites year after year. Because the Matthew Effect exists in online market, this paper examines the reasons of websites' financial losses by applying the Bertrand Model of Game Theory, and hence puts forward the pricing strategies for $\mathrm{B} 2 \mathrm{C}$ websites to turn their losses into gains.
\end{abstract}

Keywords—Bertrand Model; B2C websites; pricing strategies

\section{INTRODUCTION}

With the popularity of computer network, more and more netizens try to use electronic commerce. According to the Research Report on China's Online Shopping Market in 2015 issued by China Internet Network Information Center (CNNIC), by the end of December of 2015 the size of China's online shopping consumers had reached 0.413 billion which was the $43.9 \%$ of the whole netizen population. In 2015, China's amount of online shopping transactions had reached 3880 billion Yuan, an increase by $33.3 \%$ compared to that of last year.

Facing such an enormous Internet business market, every single electronic commerce website has been sparing no effort to attract customers with the attempt to increase the volume of transactions by enhancing network traffic and conversion efficiency. Because the Matthew Effect of "the strong become stronger while the weak become weaker" exists in the Internet economy, a large majority of consumers will concentrate in some particular famous websites of electronic commerce, thus making those websites predominant with largest shares in China's B2C transactions. On the contrary, large amount of profits did not happen with the large volume of transactions, but even losses occurred on a yearly basis to major B2C websites such as the Jingdong, Dangdang, and Amazon and so on. By exploring the causes of such losses, we can find that most of them adopted the simple low-pricing strategy, which caused seemingly increasing volume of transactions but business operation in long-lasting debt during the profit making process. Therefore, researching on the pricing strategies of electronic commerce websites can help with establishing a profitable model for these business websites, and promoting the sustainable and healthy development China's electronic commerce industry.

\section{CHARACTERISTICS OF ELECTRONIC COMMERCE TRANSACTIONS}

Electronic commerce market has its own unique characteristics compared to traditional markets, so some conventional economic theories cannot fully explain some phenomena related to electronic commerce market.

\section{A. Transactions Are not Limited to Time and Space, and Are Made very Conveniently and Quickly}

The biggest difference between electronic commerce and real tangible market lies in that electronic commerce transactions have no time and space limitations. As long as a product is on sale on a website, buyers can purchase it via the Internet anytime no matter where the product is. The circulation of commodities breaks geographical barriers and makes the economic globalization happen. Therefore, competitions among companies are not confined to a certain region but become global, and consumers can enjoy the benefits of convenient and fast service due to global competitions among companies worldwide.

\section{B. Prices Are Transparent and there Is no Asymmetric Information}

Because asymmetric information exists in tangible markets, companies can design different prices according to different regions or different consumer groups to achieve higher amount of profits. However, due to the transparent price information of online business market, asymmetric information does not exist between buyers and sellers and thus the differential pricing of the same particular commodity will make consumers intend to choose a lower price seller. Price advantages have become one kind of sources of supplier competitiveness, which is also a primary cause of Internet pricing war.

\section{Matthew Effect Exists in the Internet Economy, and the Majority of Consumers Concentrate on Major Online Shopping Websites}

Electronic business transactions also contain some risks such as lacking in face-to-face communication, depending on photo and literal descriptions of a commodity, processing payment totally online, insufficient safety guarantee, and so on, all of which lead consumers to choosing major websites 
for online shopping for their high reputation and ample commodity supply, thus forming the Matthew Effect in the Internet economy.

This phenomenon is also very prominent in domestic B2C market, as we can see from the below China Network Retail B2C Market Annual Report ("Table I") issued by Analysis that among the top $8 \mathrm{~B} 2 \mathrm{C}$ websites there is a distinctive gap between top 8 and top 1 in the volume of transactions, the former being $1.8 \%$ of the latter. These figures indicate the unitary and concentrating nature of consumers during online shopping.

TABLE I. MARKET SHARE OF CHINA's B2C ONLINE RETAILERS IN 2015

\begin{tabular}{|c|l|l|l|l|}
\hline $\begin{array}{c}\text { Rank- } \\
\text { ing }\end{array}$ & $\begin{array}{c}\text { Website } \\
\text { Name }\end{array}$ & \multicolumn{1}{|c|}{$\begin{array}{c}\text { Commodity } \\
\text { Category }\end{array}$} & $\begin{array}{c}\text { Company } \\
\text { Type }\end{array}$ & $\begin{array}{c}\text { Market } \\
\text { Share }\end{array}$ \\
\hline $\mathbf{1}$ & tmall.com & $\begin{array}{l}\text { general } \\
\text { merchandise }\end{array}$ & online & $56.8 \%$ \\
\hline $\mathbf{2}$ & Jingdong & $\begin{array}{l}\text { general } \\
\text { merchandise }\end{array}$ & online & $22.4 \%$ \\
\hline $\mathbf{3}$ & Suning & $\begin{array}{l}\text { digital and home } \\
\text { applliances }\end{array}$ & traditional & $3.2 \%$ \\
\hline $\mathbf{4}$ & Vipshop & clothing & online & $2.9 \%$ \\
\hline $\mathbf{5}$ & Gome & $\begin{array}{l}\text { digital and home } \\
\text { applliances }\end{array}$ & traditional & $1.3 \%$ \\
\hline $\mathbf{6}$ & Dangdang & $\begin{array}{l}\text { general } \\
\text { merchandise }\end{array}$ & online & $1.1 \%$ \\
\hline $\mathbf{7}$ & amazon.cn & $\begin{array}{l}\text { general } \\
\text { merchandise }\end{array}$ & online & $1.1 \%$ \\
\hline $\boldsymbol{8}$ & Yihaodian & $\begin{array}{l}\text { general } \\
\text { merchandise }\end{array}$ & online & $1.0 \%$ \\
\hline & Others & \multicolumn{2}{|l}{} \\
\hline
\end{tabular}

III. THE BERTRAND MODEL

The Bertrand Model was proposed by French mathematician Bertrand in 1883 about the pricing competition between duopolies. Different from the Cournot Model, the Bertrand Model utilizes price instead of quantity of production as the decision-making variant for assessing the gaming companies involved.

\section{A. Hypotheses in Bertrand Model}

1) The bertrand model is based on the following hypotheses

- There are only company and company b existing in the market/industry.

- Each of the two companies produces and sells the same amount of commodities.

- The marginal cost of production is constant.

- Two companies share the same market demand linear function.

- Each company presumes the cost of a rival product is fixed, or rather, the price is absolute.

- The timings of pricing are simultaneous without differences.

- Consumers intend to buy commodities of lower prices, and will only buy from one company if its price is lower than the other; consumers will buy half of commodities from one company and buy another half from the other company if the prices are the same.

2) The model constructing of bertrand model

If $\boldsymbol{Q}$ stands for market demand, $\boldsymbol{P}$ stands for price, then the market demand curve is $\boldsymbol{Q}=\boldsymbol{a}-\boldsymbol{b} \boldsymbol{P}$; The price of Firm $\mathrm{A}$ is $p_{1}$, the price of Firm B is $p_{2}, c_{\text {stands for production }}$ cost, $\pi_{1}$ and $\pi_{2}$ stand for profits of Firm A and Firm B respectively, and then the profits of Firm A and Firm B can be shown respectively in the following equations:

$$
\begin{aligned}
& \pi_{1}\left(p_{1}, p_{2}\right)=\left\{\begin{array}{cc}
\left(a-b p_{1}\right) *\left(p_{1}-c\right) & p_{2}>p_{1}>0 \\
\frac{1}{2}\left(a-b p_{1}\right) *\left(p_{1}-c\right) & p_{2}=p_{1}>0 \\
0 & p_{1}>p_{2}>0
\end{array}\right. \\
& \pi_{2}\left(p_{1}, p_{2}\right)=\left\{\begin{array}{cc}
\left(a-b p_{2}\right) *\left(p_{2}-c\right) & p_{1}>p_{2}>0 \\
\frac{1}{2}\left(a-b p_{2}\right) *\left(p_{2}-c\right) & p_{2}=p_{1}>0 \\
0 & p_{2}>p_{1}>0
\end{array}\right.
\end{aligned}
$$

Accordingly, for the pricing strategies in the Bertrand Model to secure market demand, the pricing of one firm should be lower than that of the other while maintaining a higher marginal cost $M C$ ). Therefore, the price response function of Firm A can be shown as the following:

$$
\begin{aligned}
& p_{1} \geq M C \\
& p_{1}=p_{2}-\varepsilon(\varepsilon \geq 0)
\end{aligned}
$$

The price response function of Firm A can be shown as the following:

$$
\begin{aligned}
& p_{2} \geq M C \\
& p_{2}=p_{1}-\varepsilon(\varepsilon \geq 0)
\end{aligned}
$$

So for Firm A and Firm B to reach the Nash Equilibrium Point, the following equation must be fulfilled:

$$
p_{1}=p_{2}=M C
$$

This can be shown as the following "Fig. 1".

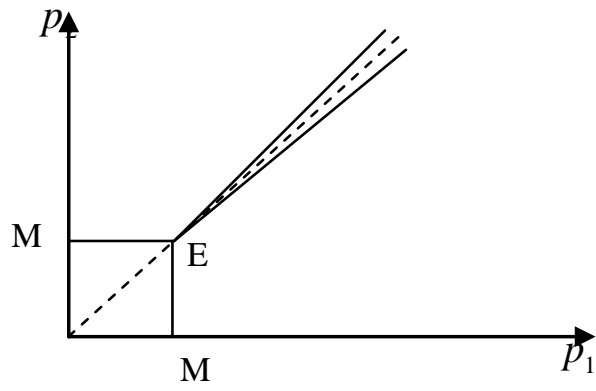

Fig. 1. Nash equilibrium point in bertrand model. 


\section{THE APPLICATION OF THE BERTRAND MODEL}

On the current B2C market of electronic commerce of China, due to the concentration of the majority consumers' online transactions on some particular major online shopping websites with almost the same quality commodities on sale and with transparent pricing, price is the key determinant factor for consumers to choose from which website to buy. All these basically meet the hypotheses of the Bertrand Model, so the analysis of B2C websites' losses is made based on the Bertrand Model in this paper.

According to the Bertrand Model, if all these websites reach the Nash Equilibrium, then the pricing of commodities should be the same, and every website firm gain an equal share of the market. However, when the price of a certain website firm is lower than its marginal cost ( $M C$ ), consumers will tend to buy commodities from that website firm only, and thus the amount of sales of other websites will be reduced to 0 , forcing them to lower their prices to ensure their market shares. However, lowering the price has its limit. When the price is lower than the marginal cost or even the total cost, seemingly the high sales could bring about large loss, and as a result, consumers will benefit from low pricing in the short term, but in the long term the firm must reduce service or product quality to reduce cost or even withdraw from market due to incapability of maintaining functional operation. When there is only one website left on the market without any new ones, the initiative right of pricing will fall to the only one website left and consumers have to settle for its pricing, the market then is turned into a monopolized one. However, monopoly is harmful to the sustainable and healthy development of electronic commerce.

\section{THE MAKING OF PRICING STRATEGIES}

Each firm should make reasonable profits so that electronic commerce market can enjoy a sustainable and healthy development. If a firm wants to achieve profits that are more than marginal cost, it must practice some other strategies.

\section{A. Adopting Differentiated Products or Service to Enhance Competitiveness}

B2C websites can attract customers by selling differentiated products and thus gain more market shares. If the products of one website are different from those of other websites, when choosing commodities consumers will not only consider the price, but they will also take into account of the substitute nature of a product and personal inclination. At this point, the price of a product can be set higher than its marginal cost. In the meantime, websites can also attract customers' eyeballs by improving service and thus consumers will not only consider the cost but also they can weigh comprehensively the product and the service of the websites. By doing so, the price can also be set higher than the marginal cost.

\section{B. Setting the Price via Collaborative Gaming}

If websites can practice collaborative gaming among each other, then websites can make excess profits by adopting collaborative pricing. By sharing information and communication, websites can set prices higher than marginal costs for products of the same category to make more profits by possessing equal market shares. However, adopting collaborative gaming requires all websites involved to abide by contracts, because one website can take more market shares than others once it breaks the contracts and lower its prices beforehand.

\section{Setting the Price through Product Mix}

Because major B2C websites are different from normal firms in that they have enormous amounts of commodities of up to millions of kinds, product mix pricing should be considered while we apply the Bertrand Model. For example, we can set a price lower than the marginal cost or the whole cost of a certain product, but another kind of product must be purchased at the same time for the consumer to enjoy that price, etc.; Tie-in sales or bulk sales can be used to lower the price, and then more customers will be attracted and larger market shares will be taken.

\section{CONCLUSION}

The Bertrand Model can well explain why websites are practicing price strategies that reduce them to financial losses on the contrary of constantly growing sales of product in the current B2C market of electronic commerce. However, because in reality these website firms supply various sorts of commodities at large quantities, future subsequent researches based on the Bertrand Model should develop better pricing strategies to help electronic commerce $\mathrm{B} 2 \mathrm{C}$ websites to make profits, to turn losses into gains, and hence to promote the vigorous development of China's electronic commerce market.

\section{REFERENCES}

[1] Weng Shichun, Huang Wei Research on the Pricing Strategies of Smart Phones Based on Non-collaborative Gaming China's Market, Volume 11, 2013.

[2] Yang Juhong, Hao Rui, Wang Xuming, etc. The Game Model Based on Commodity Pricing Strategies Complex System and Complex Science, June 2013(Volume 10).

[3] China's Online Shopping Market Research Report 2015, CNNIC, June 2016 , http://www.cnnic.net.cn/hlwfzyj/hlwxzbg/dzswbg/201606/t20160622 _54248.htm.

[4] China Network Retail B2C Market Annual Report, Analysys Company, June 2016 , https://www.analysys.cn/analysis/8/detail/1000147/. 